\title{
EFEKTIVITAS PUPUK ORGANIK CAIR “USB” DAN SUPLEMENTASI HERBAL TERHADAP PRODUKTIVITAS RUMPUT GADJAH
}

\author{
Sufiriyanto, Sri Hastuti dan Endro Yuwono \\ Fakultas Peternakan Universitas Jenderal Soedirman
}

\begin{abstract}
ABSTRAK
Penelitian ini dilaksanakan di Eksperimental Farm, membuat pupuk organik cair dari urine sapi betina bunting difermentasi dengan penambahan herbal (buah nanas, temulawak dan mengkudu) . Untuk mengetahui uji kualitas dilakukan uji pada produktivitas rumput gajah. Proses teknologi pembuatan dimulai koleksi urine sapi bunting masing-masing 60 liter. $\mathrm{P}(0)$ tanpa perlakuan, $\mathrm{P}(1)$ urine ditambah buah nanas sebanyak $6 \mathrm{~kg}, \mathrm{P}((2)$ urine 6oliter ditambah buah nanas $6 \mathrm{~kg}$ dan temulawak seberat $6 \mathrm{~kg}$ dan $\mathrm{P}(3)$ urine ditambah buah nanas, temulawak dan mengkudu masing-masing $6 \mathrm{~kg}$, diaduk setiap hari sampai tidak mengalami fermentasi. Diuji keberhasilannya dengan eksperimental Rancangan Acak Lengkap dilanjutkan Uji beda nyata jujur produktivitas rumput gajah Penelitian dengan tiga perlakuan, aras dosis $0.5 \mathrm{ml}, 1,5 \mathrm{ml}$ dan $4,5 \mathrm{ml}$ per liter air, ulangan 3 kali per unit dan setiap unit berisi 5 stek tanaman. Variabel yang diamati meliputi : kandungan protein kasar, serat kasar, produksi bobot basah, produksi bobot kering, imbangan daun dan batang, tinggi tanaman dan jumlah tunas anakan. Hasil penelitian menunjukkan bahwa pemupukan pupuk organik cair urine sapi bunting dengan suplemntasi herbal menunjukkan produktivitas optimal 38 ton/ha ( $\mathrm{P}<0,05)$ pada pupuk organik cair suplementasi nanas (R3) dosis 4,5 ml/liter air selanjutnya $\mathrm{R} 7, \mathrm{R} 9, \mathrm{R} 4$, RR5 dan R8.
\end{abstract}

Kata kunci : pupuk organik cair, urine, produktivitas, tinggi tanaman, tunas anakan, rumput gajah

\section{PENDAHULUAN}

Eksperimental Farm Fapet berfungsi untuk mendukung program Tri Darma Perguruan tinggi, mempunyai luas lahan 3,6 Ha, lahan rumput 3 ha, lokasi kandang ternak 0,4 ha, ternak sapi perah 22 ekor laktasidengan produksi sebanyak 180 liter /hari, sapi potong sebanyak 130 ekor, kambing 15 ekor dan domba 8 ekor, ayam 5000 ekor dan unit pelayanan meliputi penelitian, kunjungan anak PAUD/TK sebanyak 1890 orang/tahun, anak siswa SD sekitar 400 orang, siswa SMP sekitar 200 orang dan SMA sekitar 150 orang. Sedangkan untuk praktikum mahasiswa peternakan sebanyak 1100 orang/tahun dan kunjungan masyarakat atau kelompok peternak sebanyak 135 orang.tahun.

Program pengembangan Eksperimental selama tiga tahun yaitu, pengolahan limbah padat (tahun pertama), pengolahan limbah cair (tahun ke 2) dan peternakan berwawasan ramah lingkungan. Pada tahun 2011 Eksperimental Farm sudah meneliti tentang pengolahan limbah membuat biogas menjadi konversi listrik dan pembuatan pupuk granul yang ditelitikan pada rumput gajah, dilanjutkan tahun 2012 dilaksanakan penelitian pupuk cair organik dari urine sapi bunting dengan metode nanometer (bekerjasama dengan Bapak Mutaqin Kudus). Adanya kunjungan kelompok peternak dan Petugas Lapangan Pemalang dan peternak yang lain menyampaikan bahwa pupuk cair yang banyak diperlukan dilapangan adalah yang dengan metode alami dan berfungsi ganda atau pupuk cair merangkap anti insektisida atau anti bakterial dan atau anti tikus.Hal ini juga disampaikan oleh PPL Tulungagung, bahwa di sana sudah marak menggunakan urine fermentasi digunakan untuk pupuk padi, sebagai pupuk organik insektisida.

Pengusul peneliti bermaksud untuk membuat pupuk cair organik bahan dasr urine sapi bunting umur 4-6 bulan,, ditrambah rimpang temulawak dan buah mengkudu, sesuai dengan penelitian yang pengusul tahun 2003, 2007, 2008 dan 2009. Untuk mengurai bau amoniak urtine digunakan buah nanas, dibiarkan satu minggu kemudian ditambahkan temulawak (Curcumae xanthoriza) dan mengkudu (Morinda citrifolia). Dengan harapan, kandungan flavanoid dan sesquiterpentenoid temulawak dan kandungan kimiawi fenol buah mengkudu yang matang dapat berfungsi sebagai insektisida, pengujian kualitas pupuk cair organik USB diuji pada produktivitas rumput gajah.

\section{METODE PENELITIAN}

\section{Materi dan bahan penelitian}

Rencana penelitian dibagi tiga kelompok, yaitu koleksi cairan sludge (1), koleksi nanas, temulawak 
dan mengkudu (2) proses pembuatan pupuk cair(3)., uji kualitas pupuk cair untuk NPK (4) dan uji produktivitas rumput gajah (5)

\section{Rancangan Penelitian}

Penelitian dilakukan dengan metode eksperimental, dengan Rancangan Acak Lengkap (RAL), Adapun macam perlakuan yang diterapkan adalah sebagai berikut :

$$
\begin{aligned}
\mathrm{Ro}= & \text { kontrol } \\
\mathrm{R} 1= & \text { Pupuk cair organik nanas dosis } 0,5 \mathrm{ml} / \text { liter } \\
\mathrm{R} 2= & \text { Pupuk cair organik nanas dosis } 1,5 \mathrm{ml} / \text { liter } \\
\mathrm{R} 3= & \text { Pupuk cair organik nanas dosis } 4,5 \mathrm{ml} / \text { liter } \\
\mathrm{R} 4= & \text { Pupuk cair organik nanas }+ \text { temulawak dosis } \\
& \text { o,5 ml/ liter } \\
\mathrm{R} 5= & \text { Pupuk cair organik nanas + temulawaky } \\
& \text { dosis } 1,5 \mathrm{ml} / \text { liter } \\
\mathrm{R} 6= & \text { Pupuk cair organik nanas + temulawak dosis } \\
& 4,5 \mathrm{ml} / \text { liter air } \\
\mathrm{R} 7= & \text { Pupuk cair organik nanas + temulawak }+ \\
& \text { mengkudu dosis } 0,5 \mathrm{ml} / \text { liter } \\
\mathrm{R} 8= & \text { Pupukcair organik nanas }+ \text { temulawak }+ \\
& \text { mengkudu dosis } 1,5 \mathrm{ml} / \text { liter } \\
\mathrm{R} 9= & \text { Pupuk cair organik nanas }+ \text { temulawak }+ \\
& \text { mengkudu dosis } 4,5 \mathrm{ml} / \text { liter }
\end{aligned}
$$

Setiap perlakuan diulang sebanyak 3 (tiga) kali, penyemprotan ditujukan pada batang daun rumput gajah, dilaksanakan satu kali per dua minggu.

\section{Analisis data}

Data yang diperoleh dianalisis dengan analisis ragam (anova), bila terdapat pengaruh perlakuan dilanjutkan dengan uji BNJ (Beda Nyata Jujur) dengan model matematis sebagai berikut (Steel dan Torrie, 1993) :
$Y_{i j}=m+a i+e i j$
$Y_{i j}$ :Nilai pengamatan
$\mu \quad$ :Nilai tengah populasi
ai :Pengaruh karbohidrat fermentabel dan bakteri asam laktat ke $\mathrm{i}$
eij :Pengaruh galat percobaan

\section{Prosedur Cara Penelitian}

a. Koleksi urine sapi perah betina bunting

b. Koleksi nanas, temulawak dan buah mengkudu

c. Membuat pupuk cair organik

d. Persiapan lahan rumput gajah, penanaman rumput gajah

e. Penyemprotan tanaman rumput gajah

f. Pemanenan rumput gajah

g. Analisis kualitas rumput gajah

Adapun variabel yang diamati adalah :

1. Produksi rumput gadjah

2. Kandungan Protein kasar

\section{HASIL DAN PEMBAHASAN}

\section{Pupuk organik cair}

Pembuatan pupuk cair organik dimulai dari koleksi urine sapi bunting umur 6 bulan, disimpan kedalam jerigen untuk dilakukan pembuatan pupuk organik cair masing-masing 60 lieter ( $\mathrm{Po}, \mathrm{P} 1, \mathrm{P} 2$ dan P3) Pada waktu pembuatan pupuk bertahap pertama urine 60 liter ditambah nanas $6 \mathrm{~kg}$ untuk P1,P2 dan $\mathrm{P}_{3}$ setelah urine dibiarkan 2 minggu, kedua ditambahkan temulawak sebanyak $6 \mathrm{~kg}$ untuk drum $\mathrm{P}_{2}$ dan $\mathrm{P}_{3}$, fermentasi selama 2 minggu, selanjutnya ketiga penambahan buah mengkudu $6 \mathrm{~kg}$ untuk drum $\mathrm{P}_{3}$, ditunggu sampai fermentasi selesai dengan tanda tidak ada panas, tutup drum tidak cembung dan pupuk menjadi dingin atau ditumbuhi belatung. Setelah pupuk oeganik cair herbal jadi, dilakukan analisis pupuk cair di Fakultas Pertanian bagian Laboratorium Sumber Daya Lahan/Ilmu tanah dengan hasil sebagai berikut:

\begin{tabular}{lcccccc}
\hline \multicolumn{1}{c}{ Parameter } & Satuan & P0 & P1 & P2 & P3 & $\begin{array}{c}\text { Permentan } \\
2011\end{array}$ \\
\hline Karbon organik & $\%$ & 2,165 & 2,322 & 2,014 & 2,387 & $>6$ \\
Nitrogen total & $\%$ & 0,315 & 0,290 & 0,367 & 0,313 & $3-6$ \\
C/N ratio & $\%$ & 6,87 & 8,01 & 5,49 & 7,63 & \\
Bahan organik & $\%$ & 3,733 & 4,003 & 3,472 & 4,115 & \\
pH H20 & $\%$ & 4,41 & 3,98 & 4,05 & 4,04 & $4-9$ \\
P2O5 total & $\%$ & 0,133 & 0,113 & 0,074 & 0,075 & $3-6$ \\
K2O total & $\%$ & 0,723 & 0,697 & 0,729 & 0,674 & $3-6$ \\
\hline
\end{tabular}

Keterangan :

a. PO urine kontrol tanpa herbal

b. P1 urine ditambah nanas

c. P2 urine ditambah nanas dan temulawak

d. P3 urine ditambah nanas, temulawak dan mengkudu

Berdasarkan hasil diatas menunjukkan bahwa pupuk cair urine sapi bunting suplemen nanas, temulawak dan mengkudu mempunyai $\mathrm{pH}$ standart dan $\mathrm{K} 2 \mathrm{O}$ total sebesar 0,729 lebih banyak dibanding kontrol sehingga memberikan pertumbuhan yang lebih baik. Hal ini sesuai dengan Rinsema (1983) yang menyatakan bahwa tanaman akan tumbuh optimal pada sekitar netral sesuai dengan jenis tanamannya dan apabila ph rendah kurang dari 5 tanaman tumbuh kurang baik. Sedangakan Syarif (1989) menyatakan bahwa tanaman tumbuh optimal dengan ph tanah sekitar 5,5 sampai 7,5 Sedangkan. Pemanenan rumput pada umur 91 hari, atau rumput menjelang berbungan sedikit mundur, hal ini dikarenakan kurangnya air pada umur 1 hari sampai 56 hari Pemotongan yang berdasarkan umur akan mempengaruhi kualitas dan produktivitas rumput, produksi rumput gajah optimal apabila dipotong umur sekitar $60-90$ hari (Reksohadiprodjo, 1994).

Pada hasil analisa pupuk cair organik urine sapi bunting suplementasi atau penambahan herbal nanas 
menunjukkan $\mathrm{C} / \mathrm{N}$ rasio 10,01. Hal ini menunjukkan bahwa semakin tinggi $\mathrm{C} / \mathrm{N}$ ratio maka semakin banyak unsur Carbon sehingga dapat meningkatkan proses fotosintesis di daun dan pertumbuhan tanaman serta dapat meningkatkan produktivitas tanaman, pada rumput gajah memberikan produktivitas seberat 70 ton per Ha dengan dosis 4,5 ml per liter air $(\mathrm{P}<0,05)$. Sesuai dengan Amirullah (2008)yang menyatakan bahwa urine sapi bunting dapat digunakan sebagai pupuk cair, sebaiknya urine dilakukan fermentasi lebih dahulu, fermentasi menggunakan gula merah, rempah2 dan bantuan mikroba dekomposer.Selain dapt meningkatkan perangsangan pertumbuhan akar dan daun, juga dapat bersifat pembasmi hama atau pestisida untuk penyakit keriting daun akibat serangan serangga (thrip) Pada hasil analisa pupuk organik cair menunjukkan $\mathrm{N}$ pada suplementasi nanas lebih rendah dengan yang lainnya tetapi secara analisis menunjukkan signifikan berbeda $(\mathrm{P}<0,05)$ produksi paling optimal apad R 3 atau suplementasi nanas. Hal ini sesuai dengan Unsur $\mathrm{N}$ diperlukan oleh tanaman, salah satunya sebagai penyusun klorofil (Dwijoseputro, 1995). Tumbuhan menangkap cahaya menggunakan pigmen klorofil yang memberi warna hijau pada tumbuhan. Klorofil menyerap cahaya yang akan digunakan dalam proses fotosintesis meskipun seluruh bagian dalam tumbuhan yang berwarna hijau mengandung kloroplas, namun sebagian energi dihasilkan di daun(Kimball, 1983). Peranan $\mathrm{N}$ bagi tanaman untuk merangsang pertumbuhan, pembentukan warna hijau daun yang sangat berguna dalam proses fotosintesis. Fotosintesis merupakan proses dimana $\mathrm{H}_{2} \mathrm{O}$ dan $\mathrm{CO} 2$ oleh klorofil dengan bantuan sinar matahari diubah menjadi zat organik karbohidrat. Tanaman $90 \%$ dari bobot bahan keringnya terdiri dari tiga macam elemen yaitu $\mathrm{C}, \mathrm{H}$, dan $\mathrm{O}$ (dari udara dan air) yang ketiganya tergabung di dalam karbohidrat, hal ini berarti bobot kering tanaman sebagian besar ditentukan oleh bobot dinding selnya, yang mana dinding sel sebagian besar tersusun dari selulosa (Agustina, 1990).

Produktivitas rumput gajah meningkat akibat pengaruh unsur Nitrogen dari urine sapi bunting tersebut pada R6 (P2 urine ditambah nanas dan temulawak) dengan dosis $4,5 \mathrm{ml} /$ liter air, sesuai dengan Andi Putranto (2009) yang mengatakan bahwa pupuk urine mempunyai kelebihan : mempunyai jumlah kandungan Nitrogen, fosfor, kalium dan air lebih banyak dibanding pupuk dari kotoran ternak, sebagai perangsang tumbuh, dan bau khas urine ternak dapat mencegah hama tanaman, serta urine mengandung Nitrogen 1\%, fosfor 0,5\%, Kalium 1,5\% dan air 92\%. Didalam urine sapi mengandung hormon auksin atau hormon pertumbuhan tanaman karena sapi makan rumput dan hormon auksin letaknya di pelepah daun (Sudarto, 2005)

Hasil kualitas pupuk organik cair sangat dipengaruhi cara pembuatan pupuk cair tersebut, hal ini sesuai dengan Martinsari (2010) bahwa jika limbah peternakan urin sapi diolah menjadi pupuk organik mempunyai efek jangka panjang yang baik bagi tanah, yaitu dapat memperbaiki struktur kandungan organik tanah karena memiliki bermacam-macam jenis kandungan unsur hara yang diperlukan tanah selain itu juga menghasilkan produk pertanian yang aman bagi kesehatan. Sehingga, diharapkan bahwa usaha peternakan sapi yang dilakukan merupakan usaha peternakan yang zero waste dan ramah lingkungan.. Pupuk cair organik berada pada posisi antara pupuk organik padat dan pupuk kompos. Pupuk organik cair mempunyai keistimewaan mengandung 16 unsur hara yang sangat dibutuhkan oleh tanaman, yaitu : unsur hara makro primer meliputi $\mathrm{C}, \mathrm{H}, \mathrm{O}$ dan $\mathrm{N}$; unsur hara makro sekunder meliputi $\mathrm{Ca}, \mathrm{S}$ dan $\mathrm{Mg}$; unsur hara mikro meliputi $\mathrm{Br}, \mathrm{Cl}, \mathrm{Cu}, \mathrm{Mn}, \mathrm{Zn}$ dan $\mathrm{Mb}$ (Kamariah, dkk, 2008) Pemanfaatan pupuk cair dapat ditambahkan rempah2 supaya dapat berfungsi ganda sebagai pupuk dan pestisida nabati (Sirajudin, 2006)

\section{Produktivitas Rumput Gajah}

Penelitian rumput gajah dimulai sejak 21 Juli 2013, dilakukan penyiraman pertama umur tanaman 17 hari, diharapkan akar sudah mulai tumbuh . Penyiraman dengan dosis $0,0 \mathrm{ml} / \mathrm{l} ; 0,5 \mathrm{ml} / \mathrm{l} ; 1,5 \mathrm{ml} / \mathrm{l}$ dan $4,5 \mathrm{ml} / \mathrm{l}$, setiap unit berisi 5 tanaman, setiap tanaman disiram air pupuk cair sebanyak 1 liter. Penyiraman dilaksanakan setiap minggu karena musin kemarau, apabila musim hujan penyiraman dilakukan setiap 2 minggu sekali, karena musim kemarau maka penyiraman dilakukan $3 \mathrm{X}$ dalam satu minggu . Hasil panen rumput gajah yang biasanya 60 hari sampai 90 hari defoliasi pertama ternyata mundur sampai 112 hari, dalam arti rumput gajah dipanen setelah tinggi sekitar 1,5 meter bahkan sudah ada yang mencapai 2 meter lebih,. Hal ini sesuai dengan Sumarsono dkk (2006) yang menyatakan bahwa produktivitas dan nilai gizi rumput gajah dipengaruhi oleh banyak faktor, salah satunya faktor umur dan faktor kesuburan tanah (Dhalika dkk., 2005).

Hasil analisa menunjukkan bahwa produktivitas optimal pada rumput gajah yang diberikan pupuk cair urine sapi bunting dengan suplementasi nanas dosis $4,5 \mathrm{ml} /$ liter air. Produksi rumput gajah per unit sebanyak 70 ton/ha, sesuai dengan Reksohadiprodjo (1994) yang menyatakan bahwa produksi rumput gajah pada interval pemotongan 60-90 hari adalah 6272 ton/ha , diperkirakan penambahan nanas berhasil membantu merombak protein sehingga terlihat kandungan Nitrogen sebanyak 0,290\% sedangkan kontrol sebanyak 0,315\%. Buah nanas (Ananas 
ccomosus (L) Merr mempunyai efek sebagai anti inflamasi, antioksidan, anti inmflamasi, antibakteri dan antifungi. Mengandung zat aktif vitamin A, vit $\mathrm{C}$, Calsium, Phospor, $\mathrm{Mg}, \mathrm{Fe}, \mathrm{Na}, \mathrm{K}$, dextraosa, sukrosa, enzim bromelin, saponin, flavonoid dan polifenol. Saponin berefek anti fungi, antibakteri, anti inflamasi dan efek sitotoksik sedangakn flavonoid bersifat anti bakteri, antifungi, anti viral, anticancer dan antioksidan, untuk polifenal berfungsi sebagai antiinflamasi, antifungi, antibakteri, anticancer dan antioksidan. Hal ini sesuai juga dengan Harjadi (1993) yang mengatakan bahwa produktivitas rumput dipengearuhi oleh faktor vegetatif atau pertumbuhan karena pada waktu tanaman tumbuh sangat membutuhkan unsur karbohidrat, apabila karbohidrat berkurang maka pembelahan sel menjadi lambat maka perkembangan sel tanaman menjadi lambat. Unsur Nitrogen berfungsi untuk pertumbuhan dan pembentukan sel vegetatif, meningkatkan pertumbuhan tanaman, menyehatkan pertumbuhan daun, meningkatkan kadar protein dalam tubuh tanaman, meningkatkan kualitas tanaman penghasil daun serta meningkatkan mikroorganisme dalam tanah.

Hasil penelitian menunjukkan produktivitas cukup optimal pada pupuk organik cair dengan suplementasi nanas, temulawak dan mengkudu (R7 dan R9) dengan produksi rumput basah sebesar 50 ton/ha, hal ini dikarenakan kandungan kimiawi temulawak (fitokimiawi) kurkuminoid (kurkumin, desmetoksikurkumin), minyak atsiri (Kamfer, sikloisopren, mirsen, p-tolilmetilkarbonol) dan xantoriza, dimanfaatkan untuk peningkatan nafsu makan (Sirait, l983; Atih, 1993 ), sebagai kolagoga, menetralisir racun atau hepatotoksik dan untuk mengobati penyakit hati (Dalimarta, 2000; Sujono, 1993) Minyak atsiri (thymol dan carvacral) berfungsi sebagai anti bakteri, anti oksidan, anti sititoksik, penghambat pertumbuhan sel kanker dan antikoksidiosis (Gill, 1999). Sedangkan Atih (1993) mengatakan bahwa rimpang temulawak mengandung air sekitar $75 \%$, karbohidarat 29-34\% dan minyak atsiri 6-10 \% dan pigmen kurkuminoid sekitar 0.02-2\% (kurkumin sekitar 50-71\% dan desmeoksikurkumin sekitar 29-41\%) Kurkumin dapat mencegah Flu burung karena bersifat antisitokin, sedangkan ayam yang terinfeksi Flu burung terjadi peningkatan sitokin (Nidom, 2005). Sedangkan Sumardi dan Lasmono (2006) mengatakan ekstrak rempah (temulawak, temu ireng, jahe, cabe jawa) dan buah maja dapat untuk menanggulangi virus dari Flu burung. Sedangkan produktivitas baik $(\mathrm{P}<05)$ terjadi pada R7 pemberian penambahan mengkudu pada pupuk organik cair dikarenakan mengkudu bersifat antiviral, anti bakterial dan antikanker. Hal ini sesuai dengan penelitian Sufiriyanto dkk (2002) bahwa pemberian ekstrak mengkudu dan temulawak $10 \%$ b/v pada ayam broiler dapat menurunkan kolesterol) dan meningkatkan titer antibodi terhadap penyakit ND (Pramono et.al., 2002), menekan angka kematian atau mortalitas dan menekan konversi pakan (Guritno et al., 2002), secara kualitatif memberikan hasil positif pada gambaran darah (nilai vital hematologis) yaitu jumlah sel darah merah dan kadar hemoglobin (Sufiriyanto dan Indradji, 2002) Sedangkan pemberian ekstrak mengkudu dosis $1 \mathrm{~g}$ per liter dan probiotik 1 $\mathrm{ml}$ per liter air minum dapat meningkatkan indeks produksi dan sebagai imunostimulator penyakit ND (Sufiriyanto dan Indradji 2006), ekstrak temulawak dan kunyit dapat meningkatkan titer kekebalan AI (Sufiriyanto dan Indradji, 2007).

\section{Kandungan Protein kasar}

Protein kasar hasil analisis menunjukkan optimal pada pupuk organik cair dengan suplementasi buah nanas pada dosis 4,5 ml/liter air, karena $\mathrm{C} / \mathrm{N}$ rasio menunjukkan 8,01. Hal ini sesuai dengan Isroi (2009) yang menyatakan bahwa pemupukan tanaman dengan unsur Nitrogen dan pospor akan mempercepat pertumbuhan bagian vegetatif tanaman, meningkatkan pertumbuhan tanaman, menyehatkan tanaman, menyehatkan daun, meningkatkan kandungan protein dalam tanaman, meningkatkan kualitas daun serta meningkatkan unsur hara tanah. Pada penelitian pemanenan mundur 22 hari dikarenakan awal tanam musin kemarau, sehingga kandungan protein kasar tampak menurun, Hal ini sesuai dengan Tillman dkk. (1989) yang mengatakan bahwa penundaan panen selama sepuluh hari akan menurunkan protein kasar tanaman sebesar 0,87\%. Sedangkan Minson (1990) mengatakan lebih lanjut bahwa semakin tua tanaman akan semakin menurun kandungan protein kasar pada daun dan batang. Selanjutnya Johnson, et al. (1973) menyatakan bahwa pada musim kemarau terjadi peningkatan kimiawi serat kasar dan selulose pada dinding sel tanaman. Hartadi, dkk. (1990) menyatakan bahwa kandungan nutrien yang dicerminkan dari analisis rumput gajah (Pennisetum pupureum) bagian aerial berumur dewasa (setelah 30 hari) dalam keadaan segar yaitu $16 \%$ bahan kering, 11,5\% protein kasar, 31,3\% serat kasar, 40,1\% BETN, $3,2 \%$ lemak dan $15,9 \%$ abu. Rumput gajah merupakan jenis tanaman perenial, tumbuh tegak, mempunyai perakaran dalam kuat dan berbentuk rumpun yang dapat mencapai tinggi 4 meter, serta tumbuh baik pada tanah yang subur dan lembab. 


\section{KESIMPULAN}

1. Kualitas pupuk organik cair bahan urine sapi bunting dengan suplementasi buah nanas lebih baik dibanding suplementasi temulawak dan buah mengkudu dengan $\mathrm{C} / \mathrm{N}$ rasio 8,01 .

2. Produktivitas rumput gajah optimal pada pupuk organik cair dengan bahan dasar urine sapi bunting suplementasi buah nanas pada dosis $4,5 \mathrm{ml}$ per liter air.

\section{DAFTAR PUSTAKA}

Adrianto. 2010. Pertumbuhan dan Nilai Gizi Tanaman Rumput Gajah pada Berbagai Interval Pemotongan. J. Agroland. 17 (3) : 192 - 197.

Agustina, L. 1990. Dasar Nutrisi Tanaman. Rineka Cipta. Jakarta.

Amar A.L. 1991. Pengantar Pengenalan dan Budidaya Tanaman MakananTernak. Fakultas Ilmu- Ilmu Pertanian Universitas Tadulako. Palu Amar A.L. 1991. Pengantar Pengenalan dan Budidaya Tanaman Makanan Ternak. Fakultas Ilmu-Ilmu Pertanian Universitas Tadulako. Palu

Amirullah. 2006. Pupuk cair. Diakses dari html/cara mudah fermentasi urine sapi untuk, pp 1802 yahoo.co.id

Andi Putranto. 2009.Pembuatan pupuk cair organik,File///d1.index.php.htm

Atih, 1993 Penggunaan Ekstrak Kunyit untuk infeksi bakteri saluran pencernaan Simposium Temulawak. Universitas Padjajaran. Bandung

Dalimartha, S. 2000. Resep Tumbuhan Obat untuk Menurunkan Kolesterol. Panebar Swadaya, Jakarta

Dhalika,T.,B. Ayuningsih dan A.Budiman. 2005. Efisiensi Penggunaan Ransum Lengkap (Complete Ration) Dengan Sumber Hijauan Daun Pucuk Tebu Pada Sapi Fries Holland Jantan Muda. $J$. Ilmiah Ilmu-Ilmu Peternakan .7.(2): 76-84 15 Mei 2012)

Dwijoseputro, D. 1995. Fisiologi Tumbuhan Jilid 2. Jakarta. Gramedia.

Gardner, F.P., R.B. Perace dan R.L. Mitchell. 1991. Fisiology TanamanBudidaya. Indonesia University Press. Jakarta.

Gill,C. 2000. Botanical Feed Additive. J Feed Int. 21 (4) $: 4$

Gonggo, B. M, B. Hermawan dan D. Anggraeni. 2005. Pengaruh Jenis Tanaman Penutup dan Pengolakan Tanah Terhadap Sifat Fisika Tanah pada Lahan Alang-Alang. Jurnal ilmuilmupertanian Indonesia. 7(1):44-55.

Hartadi,H., S.Reksohadiprodjo dan AD Tillman. 1986. Tabel komposisi pakan Indonesia. Gajah Mada
University Press. Yogyakarta

Isroi. 2009. Pupuk Organik Granul.http://isroi. wordpress.com/((diakses 15 Mei 2012)

Kamariah. 2009. Kombinasi Limbah Pertanian dan Peternakan sebagai Alternatif Pembuatan Pupuk Organik Cair Melalui Proses Fermentasi Aerob. Htp/53@yahoo.com

Kristanto, B. A, R. Kurniantono, dan D.W. Widjajanto. 2009. Karekteristik Fotosintesis umput Gajah (Pennisetum purpureum) dengan Aplikasi Pupuk Organik Guano. Fakultas Peternakan Universitas Diponegoro. Semarang

Lamb.J.F.S.,C.C. Sheaffer and D.A. Samac. (2003) Alfalfa: Population Density and Harvest Maturity Effect on Leaf and Stem in Alfalfa. Agronomy Journal. Vol.95. P: 635-641

Minson,D.N. 1990. The Chemical Composition and Nutritive Value of Tropical Grasses.Tropikal Grasses. Food and Agricultural Organization of TheUnited Nation. Roma

Murty, K.S., and G. Sahu. 1987. Impact of Low Ligh Stress on Growth and Yieldof Rice.p. 94.in S.K. Dey and M.J. Baig (Eds), pp 94. Weather and Rice,Proc. International Workshop on impact of Weather Parameters on Growth and Yield of Rice. IRRI. Los Banos. Phillipines.

Ni Ketut Sari, 2009. Produksi Bioethanol dari Rumput Gajah Secara Kimia.JurnalTeknik imia,Vol.4.No.1

Nur Hidayat. 2010. Aplikasi Pupuk Organik Cair Terhadap Produksi Bahan Kering, kandungan Protein Kasar, dan Serat Kasar Rumput Gajah Varietas Thailand. Jurnal Ilmiah Inkoma, Volume 21. Nomor 3

Poniman dan Mujiono. 2004. Bertanam Rumput Gajah. Balai Pustaka . Jakarta

Praono. 2002. Pengaruh Pemberian Ekstrak Mengkudu (Morinda citrifolia) dan temulawak (Curcumae xanthoriza) terhadap Jumlah Limfosit dan Titer Kekebalan ND pada Ayam Niaga Pedaging

Purbajati E.D., S. Anwar, S. Widyati, dan F. Kusmiyati. 2008. Kandungan Protein dan Serat Kasar Rumput Benggala (Panicum Maximum) dan Rumput Gajah (Pennisetum Purpureum) Pada Cekaman Stres Kering. Animal Production. 11(2) 109-115

Reksohadiprodjo,S. 1988. Pakan Ternak Gembala. BPFE. Yogyakarta

Rinsema, W.T. 1983. Pupuk dan Cara Pemupukan. Bhatara Karya Aksara. Jakarta. Hal: 23-24 Syarief,S. 1989. Kesuburan dan Pemupukan Tanah Pertanian. Pustaka Buana . Bandung. Hal:3 Siregar, M. E. 1996. Produksi dan Nilai Nutrisi Tiga Jenis Rumput Pennisetum dengan Sistem Potong Angkut. Prosiding Pertemuan Ilmiah 
Ruminansia. Jilid. I. Pusat

Siregar, M. E. 1989. Produksi dan Nilai Nutrisi Tiga Jenis Rumput Pennisetum Dengan Sistem Potong Angkut.Prosiding Pertemuan Ilmiah Ruminansia. Jilid. I. Pusat Penelitian dan Pengembangan Pertanian, Departemen Pertanian, Bogor.

Soebarinoto. 2003. Substitusi Urea dengan Bokasih Terhadap Produksi Rumput Raja. Jurnal Protein. Nomor 19 : 1259-1266.

Sofyan, L. A., L. Abunawan, E. B. Laconi, A. D. Hasjmi, N. Ramli, M. Ridla dan A. D. Lubis. 2000. Pengetahuan Bahan Makanan Ternak. Laboratorium Ilmu dan Teknologi Pakan. Fakultas Peternakan. Institut Pertanian Bogor. Bogor

Sufiriyanto, Indradji M dan Prayitno, 2002. Penggunaan Ekstraks Rimpang Temulawak dan Buah Mengkudu Untuk Meningkatkan Kualitas Kolesterol dan Trigliserida Darah Ayam Pedaging.- dipublikasikan di Media Kedokteran Hewan, UNAIR, Surabaya.

Sufiriyanto dan Indradji. M. 2005. Efektivitas Pemberian Ekstrak mengkudu (Morinda citrifolia) dan Probiotik terhadap Produktivitas dan Titer Kekebalan ND Pada Ayam Niaga Pedaging

Sufiriyanto dan Indradji, 2006. Uji Coba Lapang Efektivitas Vaksin Avian Influenza (Flu Burung) Pada Ayam Kampung di Kabupaten Banyumas (Laporan Penelitian)
Sufiriyanto dan M. Indradji. 2006. Efektivitas Vaksinasi AI (Flu Burung) pada Ayam Petelur Pasca Wabah di Kab. Banyumas.

Sumarsono,S. Anwar,S Budiyanto, D Permatasari dan D.W.Widjajanto, 2006. Penampilan Rumput Gajah (Pennisetum Purpureum) dan Kolonjono (Panicum muticum) pada Lahan Salin yang diperbaiki dengan Aplikasi Pupuk Urea dan Organik. Seminar Nasional Pengembangan Usaha Pembibitan Ternak. Universitas Sebelas Maret. Surakarta

Sumarsono. 2006.Peranan Pupuk Organik untuk Perbaikan Penampilan dan Produksi Hijauan Rumput Gajah Pada Tanah Cekaman Salinitas dan Cekaman Kemasaman. Fakultas peternakan Universitas Diponegoro. Semarang

Sirajuddin,S.Rohani,I.Rasyid.' Proses Adopsi Pembuatan Pupuk Cair Dari Urine Sapi Oleh Kelompok Ternak Sapi Potong di Kabupaten Sinjai, Propinsi Sulawesi Selatan (Naskah Publikasi, Universitas Muhamadiyah Malang)

Taiz,L and E.Zeiger. 1998. Plant Physiology. Sinauer Associates. Inc. Publisher, Sunderland. Massachussetts

Tillman,A.D., H. Hartadi, S. Reksohadiprodjo, S. Prawirokusumo dan Lebdosukojo.1989. Ilmu Makanan Ternak Dasar. Gajah Mada University Press. Yogyakarta 